Article

\title{
Experimental Study on Thermal Balance in Soft Clay Area During GSHP Operation
}

\author{
Jie Zhou ${ }^{1,2, *}$, Yiqun Tang ${ }^{1,2}$, Peng Wan ${ }^{3}$, Zeyao Li ${ }^{1}$ and Chuanhe Wang ${ }^{1}$ \\ 1 Department of Geotechnical Engineering, Tongji University, Shanghai 200092, China; \\ tangyiqun2@tongji.edu.cn (Y.T.); lzy004@tongji.edu.cn (Z.L.); 15927589940@163.com (C.W.) \\ 2 Key Laboratory of Geotechnical and Underground Engineering of Ministry of Education, Tongji University, \\ Shanghai 200092, China \\ 3 East China Electric Power Design Institute Co., Ltd., Shanghai 200092, China; wanpeng2933@ecepdi.com \\ * Correspondence: zoujer@hotmail.com
}

Received: 30 September 2018; Accepted: 22 April 2019; Published: 28 April 2019

Featured Application: This paper provides the valuable instructions for the incoming large-area utilization of GSHP system in soft clay area in coastal cities in China and the characteristic of the thermal balance in muddy soil in Shanghai should be taken account into the design and development of the operation of the GSHP system.

\begin{abstract}
Geothermal energy resources, such as a green and clean renewable energy, are utilized all over the world, especially in soft clay areas along coastal cities in China, such as Shanghai. However, the operation of the ground-buried heat exchanger potentially affects the initial temperature field and the thermal balance, which will probably result in some potential engineering or environmental problems. This paper presents results from a series of large-scale laboratory modeling experiments which were conducted to study the thermal balance in saturated soft clay during the operation of the ground source heat pump (GSHP) system. In experiments, thermal phenomena are induced by a heat exchanger which is embedded in the testing soils and investigated by temperature sensor arrays. It summarizes the experimental methodologies and presents the time-dependent temperature distribution within the testing soils both in operation stage and the re-stabilization duration. Characteristics of thermal balance are discussed in two specific parameters of relative time ratio and temperature factor by comparing summer and winter cases. The thermal mattress effect is proposed to provide valuable guidelines for the utilization and operation of the GSHP system in soft clay areas.
\end{abstract}

Keywords: GSHP system; thermal balance; relative time ratio; temperature factor; thermal mattress effect

\section{Introduction}

The ground source heat pump (GSHP) system is an innovative technology to utilize the shallow geothermal energy, via extracting heat from the ground (geothermal energy) in winter and conversely dissipating excess heat into the soil in summer. The natural ground temperature is constant under a depth of around 10-20 m like a heat source in winter and for cooling in summer. The shallow thermal energy is part of geothermal energy stored by the soil. It's stable, vast and renewable, most importantly it's clean for the environment [1-5]. The technology development of GSHP system has passed the stage of heuristic models. Well designed, installed and maintained, GSHP systems work over many decades without any technical problems. Particularly as more geo-structures are being involved in the GSHP system $[2,3,6-10]$, the application of GSHP system in Shanghai is increasing with the development of underground space construction. 
Being green, energy efficient, sustainable and stable, ground source heat pump (GSHP) systems are becoming increasingly popular for both residential and commercial heating and cooling. GSHP system provide viable, environmentally friendly alternatives to conventional heating and cooling systems. They can significantly reduce electrical energy usage and are easily used and maintained. Salvalai [11] summaries the importance of GSHP system as a substitution for oil in building energy in EU ZEB building design could be realized and $\mathrm{CO}_{2}$ emissions could be completely eliminated. So far, the design of GSHP system is mainly performed by the HVAC specialist and the system stability, efficiency, and consecutive operation are always firstly concerned in the application. The attentions are also focused on the heat exchange system, in which the depth of the heat exchanger is determined and the calculation of peak heat loading in winter and cooling load in summer are conducted. In practice, the heating load and cooling load is mostly not equal in the operation of GSHP system [12], i.e., the heat dissipated into the soil is inconsistent in amount with that extracted from the ground, which usually results in the so-called thermal imbalance. Miara et al. [13] analyzed long-term data on the temperature of heat source which showed no decrease in soil temperature. Germany has a long winter and high demand for heating. However, in Shanghai, the duration for cooling in summer is almost twice as the time of heating needed in winter. The cooling load is much greater than the heating load during the running of GSHP system. Provided that the annual heat of input and output could not approach balance and the heat dissipated is always more massive than the heat extracted, even though the temperature increment of the underground constant temperature zone is only $0.5^{\circ} \mathrm{C}$ per year, the GSHP system cannot work properly 10 years later. Most critically, once the temperature of the shallow constant temperature zone had changed, the physical and mechanical properties would be influenced attributed to the thermodynamic variation of soil surrounding the GSHP system. The thermal disturbance conducted on the original stable foundation underground soil will greatly impact the construction stability and security of the superstructures and geo-structures.

The running of the GSHP system continuously creates a hydraulic/heat sink in the surrounding area. This leads to pressure and temperature gradients, which in turn-after termination-generate heat inflow to re-establish the pre-circulation state. The nature of recovery, or re-establishment, characterizing geothermal resources contributes to their potential sustainable use. The recovery typically shows an asymptotic behavior, being fast at the start and then slowing down subsequently, and theoretically taking an infinite amount of time to reach its original state. However, practical intermittent utilization of GSHP system (e.g., 95\%) will occur much earlier, generally on time scales of the same order as seasonal alternation [14]. Consequently, the operation of the ground-buried heat exchanger potentially affects the initial temperature field and the long-term thermal balance. Thermal balance analysis is significant for the large-scale development of the GSHP system for sustainable energy usage in Shanghai, a typical city with a large field of quaternary sedimentary formations in China. However, these environmental aspects of GSHP system are rarely considered in current GSHP design. Considering the geothermal environmental stabilization, not only the energy storage but also the ecological aspects, temperature increment, which influences the initial (stable) ground temperature field, and temperature recovery time should be considered. Traditional small-scale laboratory experiments utilizing devices such as transient probes $[4,15,16]$, calorimeters, guarded heater devices, or annular thermal conductivity cells, etc., [17-27] do not collect continuous data as long term in situ conditions. In the Shanghai area, the use of the GSHP system is still in its infancy with very few installations. Soft soil is distributed widely in Shanghai, particularly the huge muddy clay soil with properties of high water content, large pore ratio, and unique aggregate structure. The special properties of the particle structure, mechanism, and thermo-physical behaviors will definitely result in the distinct temperature variation and influence the operation of GSHP system compared to the granular soils [28-35].

The research of thermal balance has been conducted during decades. However, it is mainly involved in nuclear waste management, ground soil improvement, meteorological phenomenon, global warming, seasonal frost problems, etc. [36-44]. Thermal balance was paid some attention 
recently [45-47], but it is rarely related to the soil properties or lack of instruction for the GSHP system in Shanghai.

This paper reported on large scaled physical modeling experiments which investigated the thermal balance characteristics of muddy clay in Shanghai during the operation of the GSHP system in the alternation of summer and winter cases. The variation of the temperature field and the re-stabilization circumstances for the environmental evaluation are discussed as well, via the qualitative and quantitative relations between variables of circulation temperature, distance from the GS and the temperature and time factors, respectively. All these results provide essential reference not only in the parameter design of GSHP system, but also for the assessment of environmental effects in the long-term running.

\section{Materials and Methods}

\subsection{Geology and Climate in Study Area}

The city of Shanghai locates at the mouth of the Yangtze River where it enters the East China Sea. The subsoils consist of approximately $300 \mathrm{~m}$ of loose quaternary sediments with relatively small variations in the stratigraphy (Figure 1). Because the soils are deltaic and estuarine deposits, they are typically soft in the upper $70 \mathrm{~m}$ consisting of clay, loam, silt, and sand. All the features and characteristics of the sediments show the physiographic evolution of the estuarine system. The rapid development of the Chinese economy has spurred major underground construction in Shanghai. The infrastructures were or are being constructed in the top shallow soft clayey deposit within subsurface $120 \mathrm{~m}$, mainly consisting of dark green stiff clay (known as the DGSC layer in the subsurface around $70 \mathrm{~m}$, Figure 1) with the following Upper Pleistocene (Q3), and the Upper Holocene (Q4) (the details are presented in [48,49]). Generally, the soft soil is regarded as the layers above the DGSC, in which engineering construction is more directly impacted by the third layer of muddy, silty clay and the fourth layer of muddy clay. In the meantime, it is also the shallow thermal zone that the GSHP system is commonly installed. Mostly they are buried at depths of $4 \mathrm{~m}$. Moreover, the thickness of muddy clay soil is relatively huge varying from $12 \mathrm{~m}$ to $20 \mathrm{~m}$ with the absence of the third layer in some zones. It has characteristics of high water content, large pore ratio, low strength, and high compressibility attributable to the special hydrogeology environment in Shanghai (Figure 2).

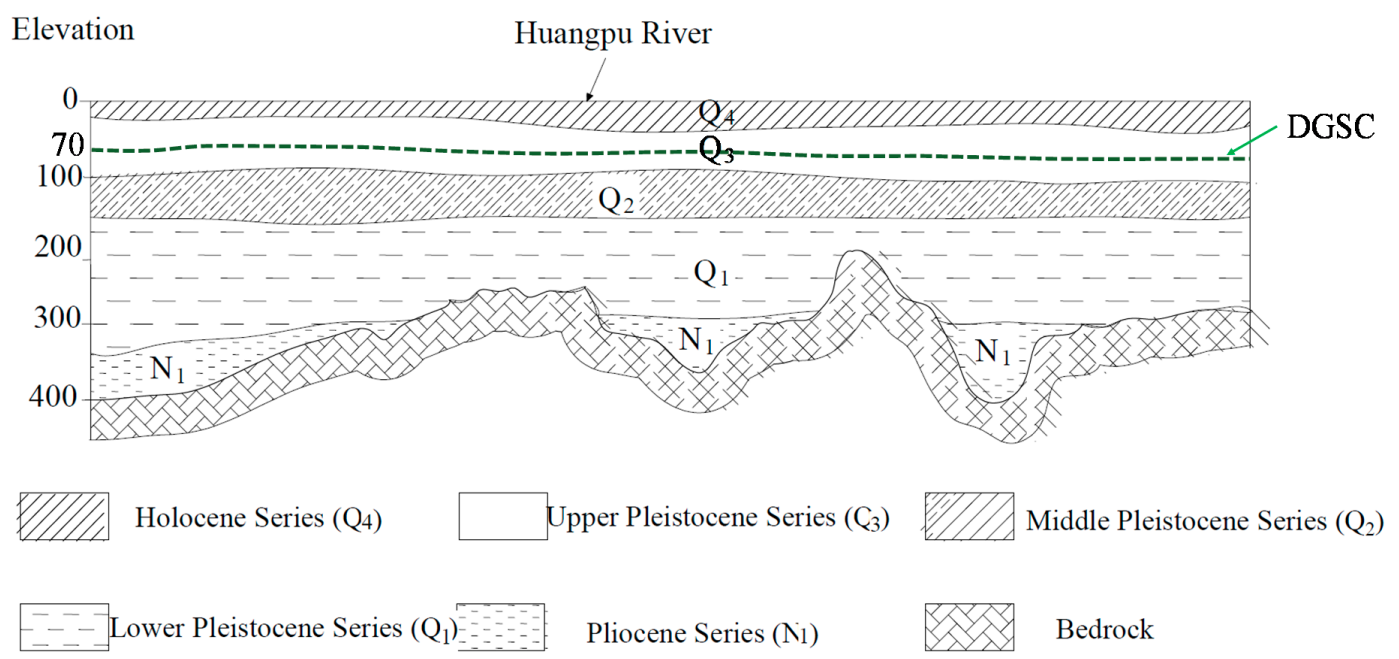

Figure 1. The typical Quaternary geological strata of Shanghai City (based on Xu, et al [48]).

Shanghai locates on a flat alluvial plain by the East China Sea, composed of Quaternary sediments of Yangtze River estuary. It has a humid subtropical climate and experiences four distinct seasons. The annual mean temperature is around $16^{\circ} \mathrm{C}$ without much difference between highest and lowest. It lasts almost 69 days in spring, 62 days in autumn (both $10^{\circ} \mathrm{C} \sim 22^{\circ} \mathrm{C}$ ), 117 days in summer $\left(\geq 22^{\circ} \mathrm{C}\right.$ ), 
and 115 days in winter $\left(<10^{\circ} \mathrm{C}\right)$. The mean hottest temperature is around $30^{\circ} \mathrm{C}$ in July and the coldest is around $3{ }^{\circ} \mathrm{C}$ in January. The surface temperature has a mean of around $35^{\circ} \mathrm{C}$ for July-August and averagely $0{ }^{\circ} \mathrm{C}$ for January-February. The annual temperature difference is so small that from the deep to the subsurface, almost $20 \mathrm{~m}$ difference, the temperature stabilizes around $17^{\circ} \mathrm{C}$.

\begin{tabular}{c|c|c|c}
\hline Depth $(\mathrm{m})$ & Figure & Soil Type & Soil Layer \\
\hline & Clay(thin layer), Silty sand & Surface soil and the first aquifer \\
\hline & & Mucky silty clay & The first compressible layer \\
\hline & & Sand & The second compressible layer \\
\hline & & Hard Clay clay & The third compressible layer \\
\hline & & & Dark green stiff clay(DGSC) \\
\hline
\end{tabular}

Figure 2. Shanghai geology and hydrology profile.

\subsection{Experimental System Design}

To acquire variations of temperature field and re-stabilization characteristics during the operation of the GSHP system in summer and winter cases in the laboratory, an experimental system should be specifically designed. One of the most important aspects considered in modeling design is scale law. The similarity ratios should be considered in many aspects to make the model and prototype consistent. In physics and engineering, the Fourier number is a dimensionless number that characterizes transient heat conduction; and the Reynolds number is an important dimensionless quantity in fluid mechanics used to help predict flow patterns in different fluid flow situations. Hence, the Fourier number and the Reynolds number are selected as similarity criterions since phenomena of heat transfer and fluid mechanics are mainly involved in this program.

Firstly, the soil thickness in prototype layer is $30 \mathrm{~m}$ (The depth of soil in field mostly involving muddy silt clay, muddy clay, and silty clay in the shallow GSHP system is around $30 \mathrm{~m}$ ). The model soil is filled to $1.0 \mathrm{~m}$ as a most appropriate size in the laboratory; then the geometry similarity ratio was calculated by $C_{l}=1.0 \mathrm{~m} / 30 \mathrm{~m}=1 / 30$, i.e., 1:30. Considering the space of installing U-tube heat exchange, instruments and some insulation materials, the model box height is set to be $1.5 \mathrm{~m}$. In addition, the influence range of $1.5 \mathrm{H}$ ( $\mathrm{H}$ is the thickness of soil) is considered according to the national standard of the Technical Code for Ground Source Heat Pump System (GB 50366-2005). Thus, the sectional model box dimension is set to be $170 \mathrm{~cm}$ (the aiming direction of temperature-sensor distribution) $\times 120 \mathrm{~cm}$.

The heat exchanger of UT is directly related to the heat transfer between the soil surrounding and UT. It plays a very important role in the model experiment. Single U-shaped PE tube is selected in this model experiment. In practice, the diameter of the PE tube is about $20 \sim 40 \mathrm{~mm}$. If the same geometry similarity ratio of 1:30 was utilized in UT, the diameter of UT can only be less than $1 \mathrm{~mm}$, which is impossible in the manufactory product. In addition, to get enough heat exchange efficiency, a certain amount of heat flux is required. Comprehensively considering the above aspects and prior to ensure the consistent $\mathrm{q}$ (heat flux per surface area) with general prototype circumstance, the geometry 
similarity ratios of UT can be set as 1:1 in cross section and 1:30 in depth (U-tube heat exchanger dimensions by such similarity ratios is $2 \mathrm{~cm}$ in diameter and $100 \mathrm{~cm}$ in height).

According to the Fourier number (similarity criterion in heat transfer), there is a similarity criterion in ratio form as: $\frac{C_{a} C_{t}}{C_{l}^{2}}=1$ where $C_{a}, C_{t}, C_{l}$ is respectively similarity ratio of thermal diffusion, time and geometry. Moreover, $C_{a}=1$ conspicuously due to the same model soil with the prototype, combined the above formula, the time similarity ratio can be yielded $C_{t}=C_{l}^{2}=(1 / 30)^{2}=1 / 900$. The time similarity ratio is $1: 900$, i.e., a unity minute in the experiment is equivalent to $900 \mathrm{~min}$ in prototype and it is about $15 \mathrm{~h}$. Therefore, the model experiment can greatly shorten the testing time (time similarity ratio is deduced by the Fourier number).

Lastly, the crux in our model tests is the temperature conduction, which is directly related to the heat flux per surface area. To ensure $C_{q}=1$, i.e., to guarantee the simulation quality, the heat flux used in the model tests should be calculated precisely to attain the same flux per surface area in the unit cylindrical heat source, and the heating power also should be controlled exactly to get the constant heat flux. The similarity ratio of the heat flux is relative to the geometry similarity ratio of $\mathrm{UT}$, i.e., $C_{V_{f}}=\left(C_{l_{1}}\right)^{2} \cdot C_{l_{2}}=1 / 30$. Moreover, the borehole depth in the prototype is mostly about $60 \sim 100 \mathrm{~m}$. The soil thickness that the model experiment simulated is $30 \mathrm{~m}$. Consequently, the fluid flow rate is determined to be $\left(V_{f}\right)_{m}=C_{V f} \cdot \frac{30}{60 \sim 100} \cdot\left(V_{f}\right)_{p} \approx\left(\frac{1}{2} \sim \frac{1}{3}\right) \frac{\left(V_{f}\right)_{p}}{30}$ where $\left(V_{f}\right)_{m}$ is the flow flux in the model; $\left(V_{f}\right)_{p}$ is the flow flux of heat exchanger in the field, and the value is mainly about $0.6 \sim 1.5 \mathrm{~m}^{3} / \mathrm{h}$ varied in different circumstances. Therefore, the value of the flux in the model experiment is about $0.67 \sim 1.0 \mathrm{~L} / \mathrm{min}$. In our model tests $1.0 \mathrm{~L} / \mathrm{min}$ is chosen for the testing flux which adds up to $0.06 \mathrm{~m}^{3} / \mathrm{h}$ (heat flux in model test).

Based on the Fourier number and analysis above, all the similarity constants are summarized in Table 1.

Table 1. Similarity ratios used in the model experiment.

\begin{tabular}{|c|c|c|}
\hline Category & Details & Similarity Ratio \\
\hline & Model box & $C_{l}=1 / 30$ \\
\hline \multirow[b]{2}{*}{ Model } & Model soil & $C_{l}=1 / 30, C_{\gamma}=1, C_{k}=1, C_{\alpha_{v}}=1$ \\
\hline & $\begin{array}{l}\text { U-shaped tube (the ground } \\
\text { heat exchanger) }\end{array}$ & $\begin{array}{c}\text { Cross-sectional: } C_{l_{1}}=1 \\
\text { Vertical: } C_{l_{2}}=1 / 30\end{array}$ \\
\hline $\begin{array}{l}\text { Heat circulation } \\
\text { system }\end{array}$ & Heat transfer parameters & $\begin{array}{c}C_{\alpha}=1, C_{V_{f}}=\left(C_{l_{1}}\right)^{2} \cdot C_{l_{2}}=1 / 30 \\
C_{q}=1 \text { where } q \text { is the heat flux } \\
\quad q=2 \pi r_{e} Q=-\frac{2 \pi a r_{e} k u_{f}}{r_{e} a \ln r_{e}-k}\end{array}$ \\
\hline Output & $\begin{array}{l}\text { Thermal response } \\
\text { parameters }\end{array}$ & $C_{\lambda}=1, C_{p}=1 / 30, C_{t}=C_{l}^{2}=(1 / 30)^{2}=1 / 900$ \\
\hline
\end{tabular}

Note: $\gamma$ is the bulk density; $k$ is the coefficient of permeability, and $\alpha_{v}$ is the coefficient of compressibility.

Winter circulation system consists of a cryostat tank with inlet and outlet silicone hoses, connecting with U-tube in model soil (Figure 3), while the summer case is running by a water chamber (with heater inside), a water pump, and a flow meter (Figure 3). $2 \mathrm{~cm}$-thick polyethylene foam is pasted on walls of model box for insulation material. It notes that the flux of circulation flow should be controlled to $1.0 \mathrm{~L} / \mathrm{min}$ in this model according to the similarity ratio so that the same heat flux per surface area compared in the prototype can be promised. 


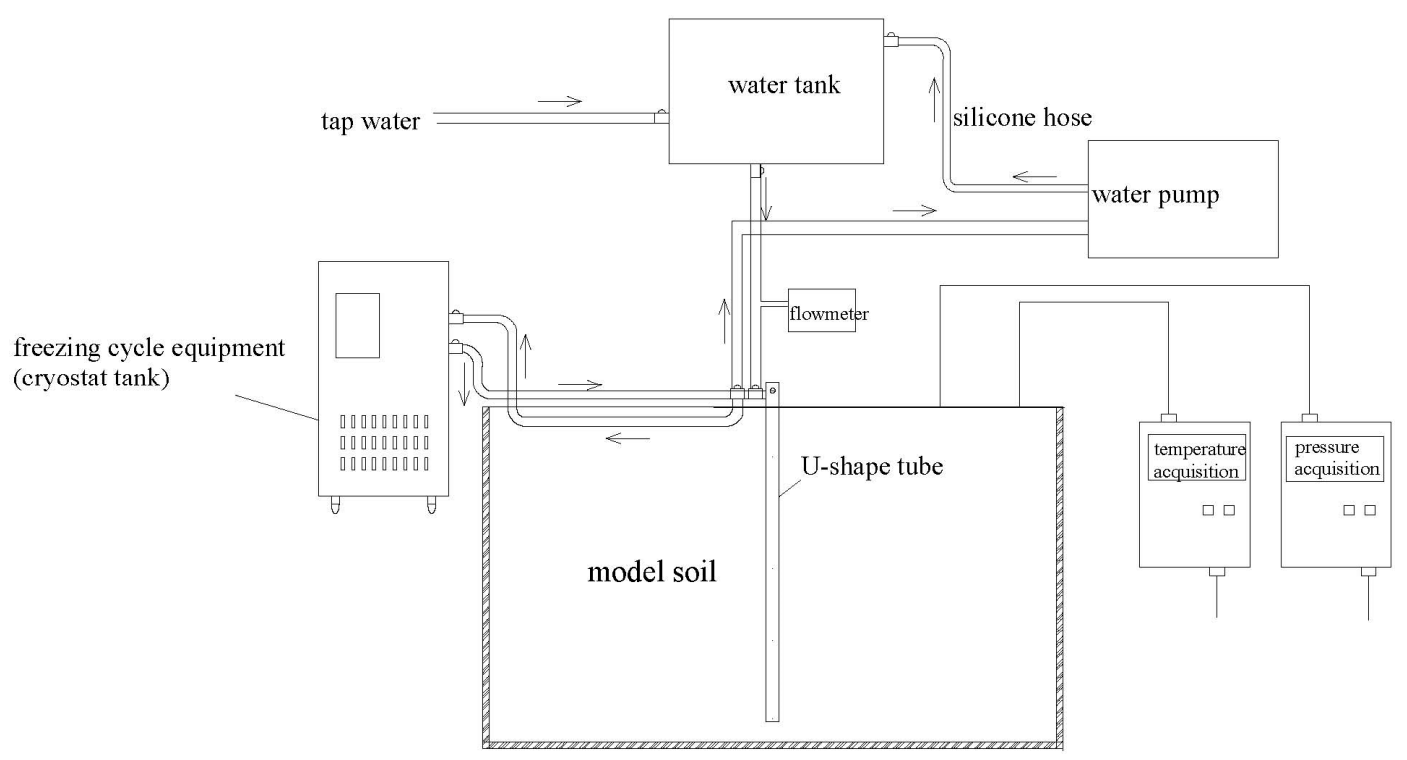

Figure 3. The experimental system schematic.

\subsection{Model Soil Preparation}

The second important part of the model experiments is model soil preparation. It is reconstituted from undisturbed soil from a typical Shanghai construction site in Tang Town of Pudong New City, east from the Huangpu River. Construction in soft clay encounters issues associated with low permeability, thixotropy, and the rheology of the muddy clay [50-53]. However, thermal properties are rarely considered. Representative and uniform soil samples were drilled out, sealed, and transported to the laboratory as soon as possible. They were kept in a curing room under constant temperature and humidity. Some soil samples used to measure the undisturbed basic parameters were penetrated by the thin-wall sampler carefully. They were shaped in a $30 \mathrm{~cm}$-height and $10 \mathrm{~cm}$-diameter cylinder under the best-undisturbed state. The physical and mechanical parameters are measured in Tables 2 and 3 to guide and control the preparation for reconstituted samples in model experiments.

Table 2. Physical properties of the model soils.

\begin{tabular}{|c|c|c|c|c|c|c|}
\hline $\begin{array}{c}\text { Soil } \\
\text { Layer }\end{array}$ & Soil Type & $\begin{array}{l}\text { Thickness } \\
\text { (m) }\end{array}$ & $\begin{array}{c}\text { Water } \\
\text { Content } w \\
\quad(\%)\end{array}$ & $\begin{array}{c}\text { Bulk } \\
\text { Density } \gamma_{0} \\
\left(k N / \mathrm{m}^{3}\right)\end{array}$ & $\begin{array}{c}\text { Specific } \\
\text { Gravity } G_{s}\end{array}$ & $\begin{array}{c}\text { Initial Void } \\
\quad \text { Ratio } e_{0}\end{array}$ \\
\hline No.3 & Muddy silt clay & $4-9$ & 39.2 & 18.3 & 2.73 & 1.08 \\
\hline No.4 & Muddy clay & $12-20$ & 49.9 & 17.2 & 2.74 & 1.39 \\
\hline No.5 & Silty clay & $1-4$ & 34.9 & 18.4 & 2.73 & 0.99 \\
\hline
\end{tabular}

Table 3. Mechanical properties of the soils.

\begin{tabular}{|c|c|c|c|c|c|c|}
\hline & Soil Type & $\begin{array}{l}\text { Coefficient of } \\
\text { Compressibility } \\
a_{v}\left(\mathrm{MPa}^{-1}\right)^{\mathrm{a}}\end{array}$ & $\begin{array}{l}\text { Coefficient of } \\
\text { Volume } \\
\text { Compressibility } \\
m_{v}\left(\mathrm{MPa}^{-1}\right)^{\mathrm{a}}\end{array}$ & $\begin{array}{l}\text { Coefficient of } \\
\text { Permeability } k_{v} \\
(\mathrm{~cm} / \mathrm{s})\end{array}$ & $\begin{array}{l}\text { Cohesion } c \\
\left(_{(\mathrm{kPa})}\right)^{\mathrm{b}}\end{array}$ & $\begin{array}{c}\text { Internal } \\
\text { Friction } \varphi\left(^{(}\right){ }^{b}\end{array}$ \\
\hline No.3 & Muddy silt clay & 0.59 & 0.28 & $1.34 \times 10^{-7}$ & 16 & 18.0 \\
\hline No.4 & Muddy clay & 1.01 & 0.42 & $4.22 \times 10^{-8}$ & 13 & 10.0 \\
\hline No.5 & Silty clay & 0.49 & 0.25 & $3.84 \times 10^{-6}$ & 16 & 14.5 \\
\hline
\end{tabular}

a: the value of $a_{v}$ and $m_{v}$ here are referred in the field geotechnical investigation report of the sampling places, which were evaluated and recommended as the value over the loading increment (100 200 kPa) according to the field stress condition; the specific testing procedure can be referred to ASTM Standard [54] for one-dimensional consolidation properties of soil using incremental loading. ${ }^{\mathrm{b}}$ : they are direct shear test values; as for muddy clay, correspondingly they are $12.5 \mathrm{kPa}$ and $13.6^{\circ}$ in undrained tri-axial compression test (CU); and the effective values are $6.9 \mathrm{kPa}$ and $24.2^{\circ}$ respectively. 
Generally, there are two kinds of reconstitution methods for model soil, i.e., slurry deposition (SD) and moist tamping (MT). Due to the different soil properties, the SD method was chosen to reconstitute muddy clay since it is fine-grained, very soft, and has a water content as high as $50 \%$. A slurry of the initial water content of $65 \%$ was made by mixing water and dry soil, thoroughly dried and pulverized from undisturbed soil, to be paved into the model box layer by layer in $2 \mathrm{~cm}$. It is better to also be tamped together to remove air bubbles. The additional water was drained out by consolidation under $1 \mathrm{~g}$ self-weight dead load for $24 \mathrm{~h}$ with additional vertical stress of $165 \mathrm{kPa}$ (pre-consolidation pressure). One pore pressure transducer was installed to monitor the consolidation process. Finally, the resulting water contents of model soils have been checked. It showed a good homogeny of $50 \% \pm 3 \%$ along the depth with a saturation level close to $100 \%$. In contrast, the MT method was used for relatively coarse-grained soil, such as silts and sands, i.e., the muddy silty clay and silty clay layers in this research program, by compacting re-constituted soils to a specific density in layers. The undisturbed soils were thoroughly dried and mixed with a pre-calculated amount of water according to a designed water content value in a mixer of a specific volume, and then stirred a lot until homogenized; finally filled into the model box in step by compaction with a hand hammer. The desired density was controlled by the number of blows per unit of soil under the MT approach [55]. The resulting saturation in MT is not as good as that in the SD, but actually it also meets the requirement for general model experiments since the main target layer is the high-thickness muddy clay in the mid part of the model soil.

As for the thickness of each kind of soil, it was determined by a geometric similarity ratio of 1:30, i.e., $30 \mathrm{~cm}$ of muddy silt clay, $60 \mathrm{~cm}$ of muddy clay, and $10 \mathrm{~cm}$ of silty clay based on field conditions (shown as Figure $4 \mathrm{a}$ ), totally amounting to $1 \mathrm{~m}$ of model soils.

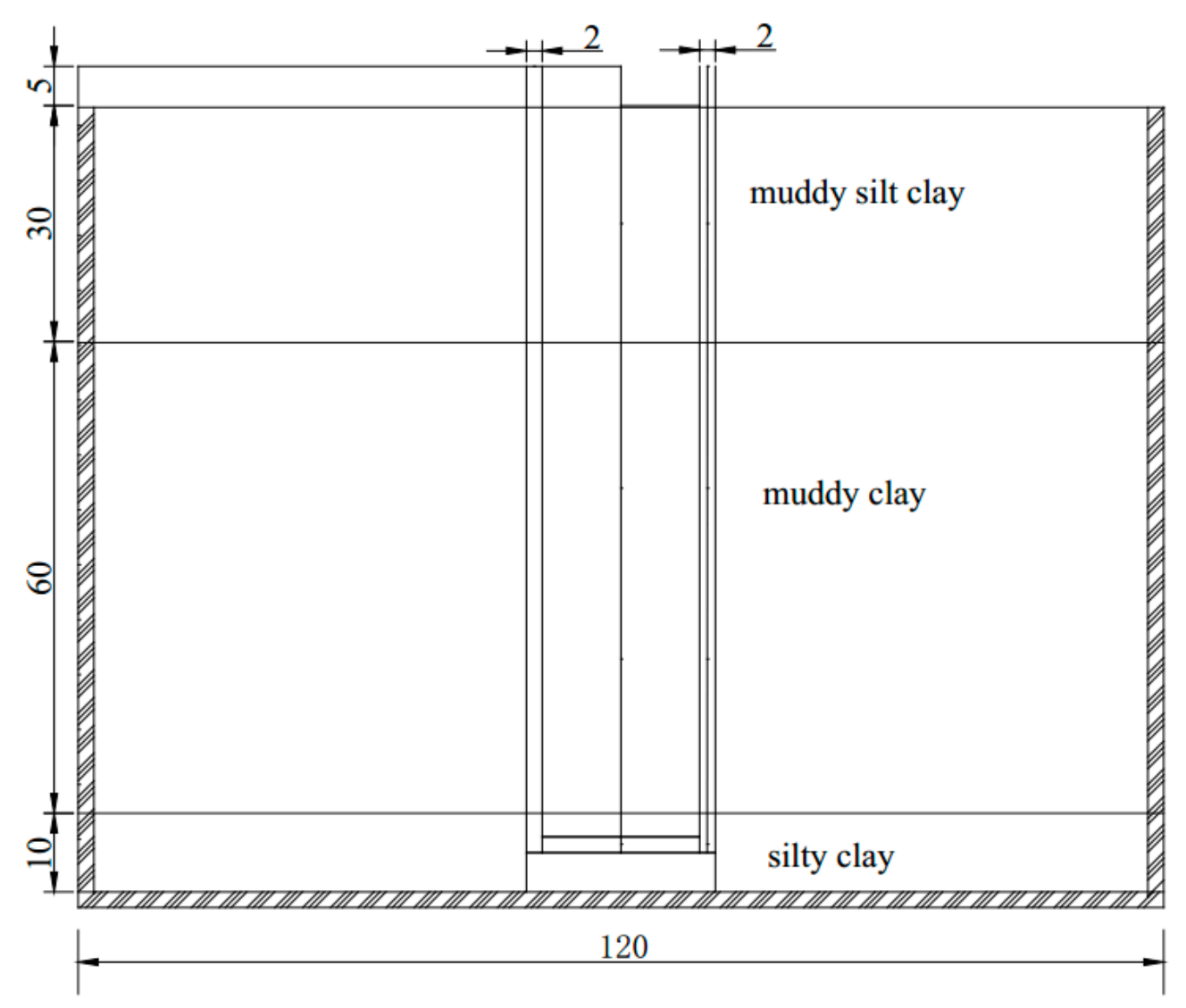

(a)

Figure 4. Cont. 


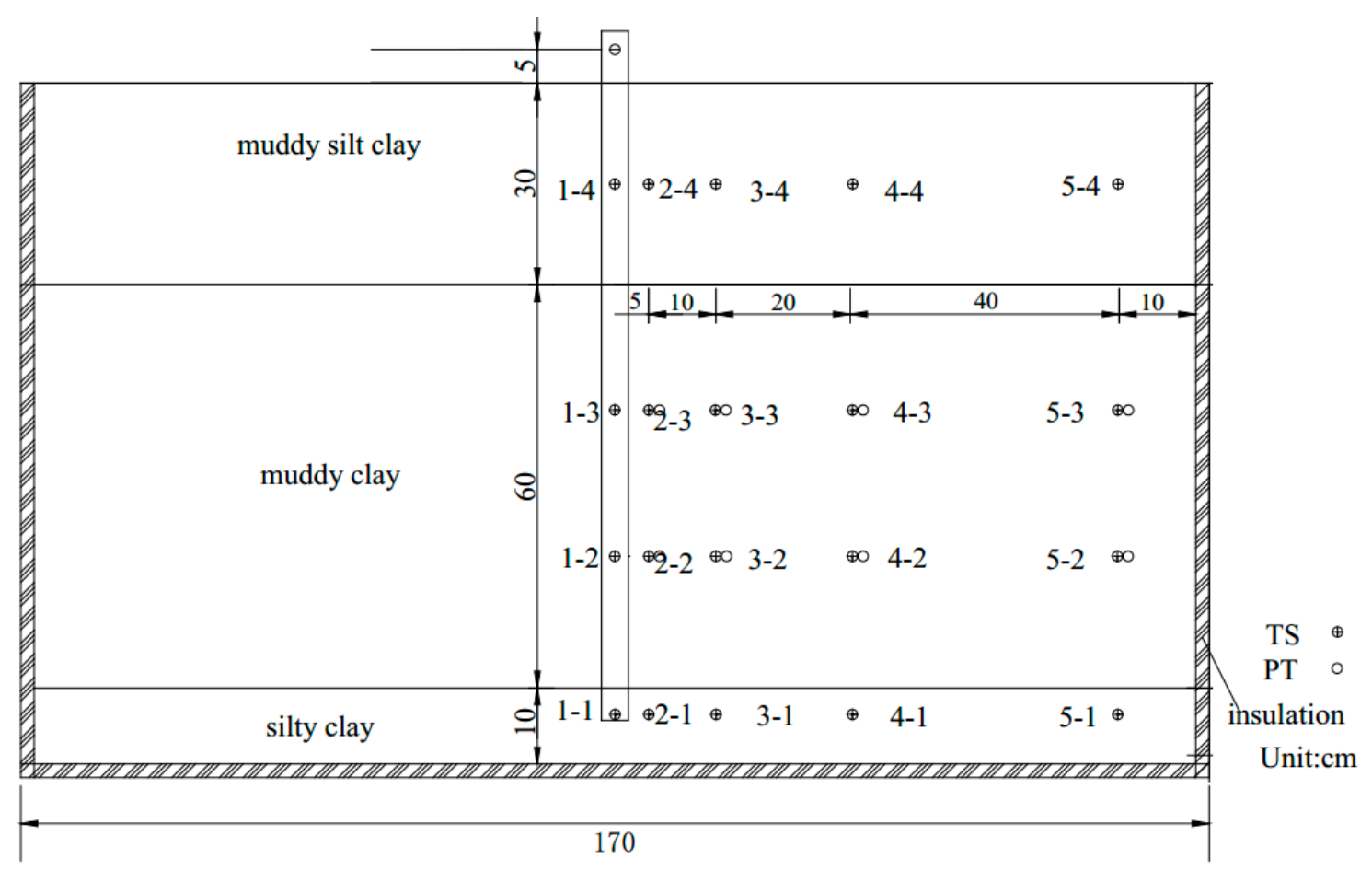

(b)

Figure 4. Experimental model box: (a) model soils distribution; (b) sensors.

\subsection{Experimental Sensors and Procedures}

In this research program, temperature sensors (TSs) and pore pressure transducers (PTs) were equipped four in an array along the depth and also five radially in the U-tube (Figure $4 \mathrm{~b}$ ) to monitor temperature distribution and the surrounding influence in soil pressure. In each TS array, there are two in the middle of the muddy clay layer and one for the muddy, silty clay layer and one for the silty clay layer. In the radial direction, TSs were placed to appropriate distances, i.e., closer to the UT, denser temperature sensors were placed $(5 \mathrm{~cm}, 10 \mathrm{~cm}, 20 \mathrm{~cm}$, and $40 \mathrm{~cm}$ exactly in Figure $4 \mathrm{~b})$. They were numbered in the array number connected with elevation number (such as 5-1 means the one in the fifth TS array at the first elevation).

To make uniform environmental conditions, the whole experimental system is equipped in a constant temperature and humidity laboratory room. Four contrast tests were respectively conducted in circulation temperatures of $35^{\circ} \mathrm{C}, 40^{\circ} \mathrm{C}, 45^{\circ} \mathrm{C}$, and $50^{\circ} \mathrm{C}$ of summer cases and $5{ }^{\circ} \mathrm{C}, 0{ }^{\circ} \mathrm{C},-5{ }^{\circ} \mathrm{C}$, $-10^{\circ} \mathrm{C}$ of winter cases. It should note here that the reconstituted model soil was re-prepared for each test to avoid water loss or structure damage during GSHP running. Before starting each circulation, the initial temperature field in soil was checked to be consistent with the original temperature in the field around $17^{\circ} \mathrm{C}$ [56]. Table 4 showed model soil temperatures measured by TSs before one of the circulations under $35^{\circ} \mathrm{C}$. To ensure the experimental system was running fluently, trial circulations were performed several circles until each part can be connected well. After the temperature stabilized during the GSHP running, the fluid circulation in UT could be stopped. However, to get the re-stabilization circumstance, the TSs should be monitored until the temperature stabilizes again after the termination of the heat exchange. The temperature value of TS 4-3 is set as the criterion for these key procedures because the aimed soil layer is muddy clay. 
Table 4. Soil temperatures measured by TSs before circulation.

\begin{tabular}{|c|c|c|c|c|c|c|}
\hline Elevation No. & TS Series & 1 & 2 & 3 & 4 & 5 \\
\hline \multirow{4}{*}{$\begin{array}{c}\text { Initial } \\
\text { temperature } \\
\left({ }^{\circ} \mathrm{C}\right)\end{array}$} & 1 & 16.78 & 16.8 & 16.47 & 16.37 & 16.84 \\
\hline & 2 & 16.83 & 16.98 & 16.67 & 16.44 & 16.03 \\
\hline & 3 & 16.91 & 16.61 & 17.27 & 16.91 & 16.4 \\
\hline & 4 & 17.45 & 17.23 & 16.63 & 17.12 & 16.95 \\
\hline
\end{tabular}

\section{Results and Discussion}

\subsection{Time-Dependent Temperature Variation During the Whole Testing Process}

The temperature variations were monitored in the whole testing process including two periods: the fluid circulation period (i.e., GSHP operation time from the starting of tests to the end of fluid circulation and recovery period, i.e., from the termination of GSHP running to the end of tests). They were divided by a red arrow line, shown in Figure 5a,b. All TSs temperature variations of $50{ }^{\circ} \mathrm{C}$ in summer case and $-10{ }^{\circ} \mathrm{C}$ in winter case are addressed respectively. Specifically, from the whole process, the time-dependent temperature curves advance in three states: temperature ascending, stable state, and recovery stage. From the concept of heat-energy in soils, it can also be regarded as heat storage (temperature increasing) and heat-release (temperature decreasing), all the curves can also be divided into three stages including heat-storing, heat equilibrium, and heat-releasing, irrespective of summer (Figure 5a) or winter (Figure 5b). From the aspect of time, the fluid circulation period includes the time of the previous two stages and the recovery period equal to the time of the recovery stage. It is surprising to notice that both figures show that after recovery time, the stable temperatures are a little bit elevated than the initial starting temperature.

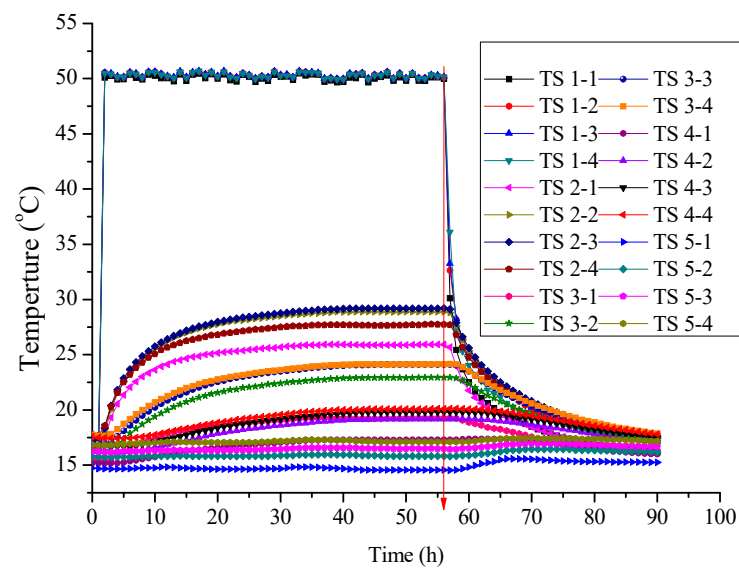

(a)

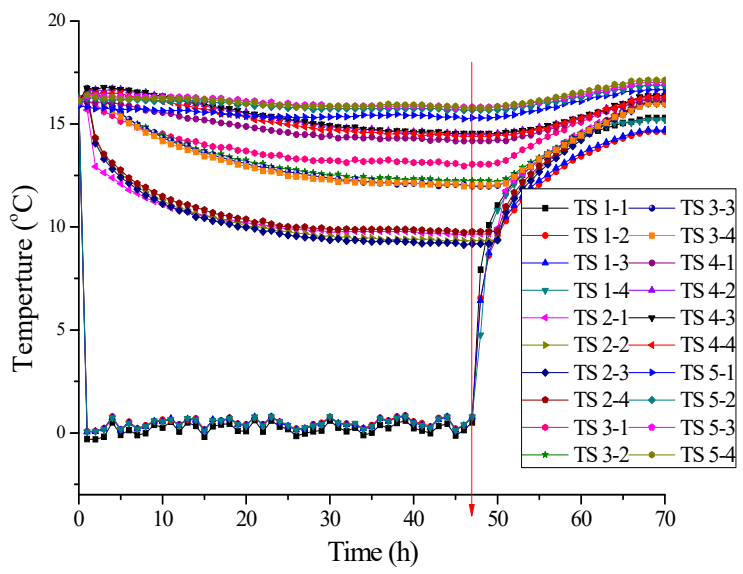

(b)

Figure 5. Temperature variations with time of No.3 TSs under a certain temperature fluid circulation: (a) $50{ }^{\circ} \mathrm{C} ;(\mathbf{b})-10^{\circ} \mathrm{C}$.

They were numbered in array number connected with elevation number (such as 5-1 means the one in the fifth TS array at the first elevation).

To better understand the radial heat influence on the temperature in soils to the U-tube, temperature variations of temperature sensors (TSs) in the same elevation number (such as 2-2, 3-2, 4-2, and 5-2) are selected, shown in Figures 6 and 7. They are located at a same depth in model soil but different distances to U-tubes. Specifically, they are arranged in a row seen from the model elevation of Figure $4 \mathrm{~b}$ and labeled as No.1 TSs, No.2 TSs, No.3 TSs, and No.4 TSs (such as No.1 TSs includes TS 2-1, TS 3-1, TS 4-1, and TS 5-1). Curves in Figure 6 note that the visible temperature influence exhibited in almost all No.1 TSs, No.2 TSs, No.3 TSs, and No.4 TSs along various distances to the U-tube. They show 
an asymptotic behavior, being fast at the start and then slowing down subsequently. This reflects characteristics of heat conduction within soils. This heat conduction is continuously induced by the heat exchange between U-tube and the surrounding soils under a constant rate (the same q), while the temperature could not increase all the time. It increased very fast firstly and then got into a stable stage. The internal motivation is the thermal gradient for temperature variation. With time advance, the difference of temperatures within the adjacent soils became smaller until a heat equilibrium state approached. At this circumstance, the temperatures could not change even GSHP kept running. The heat conduction within soils also stopped.
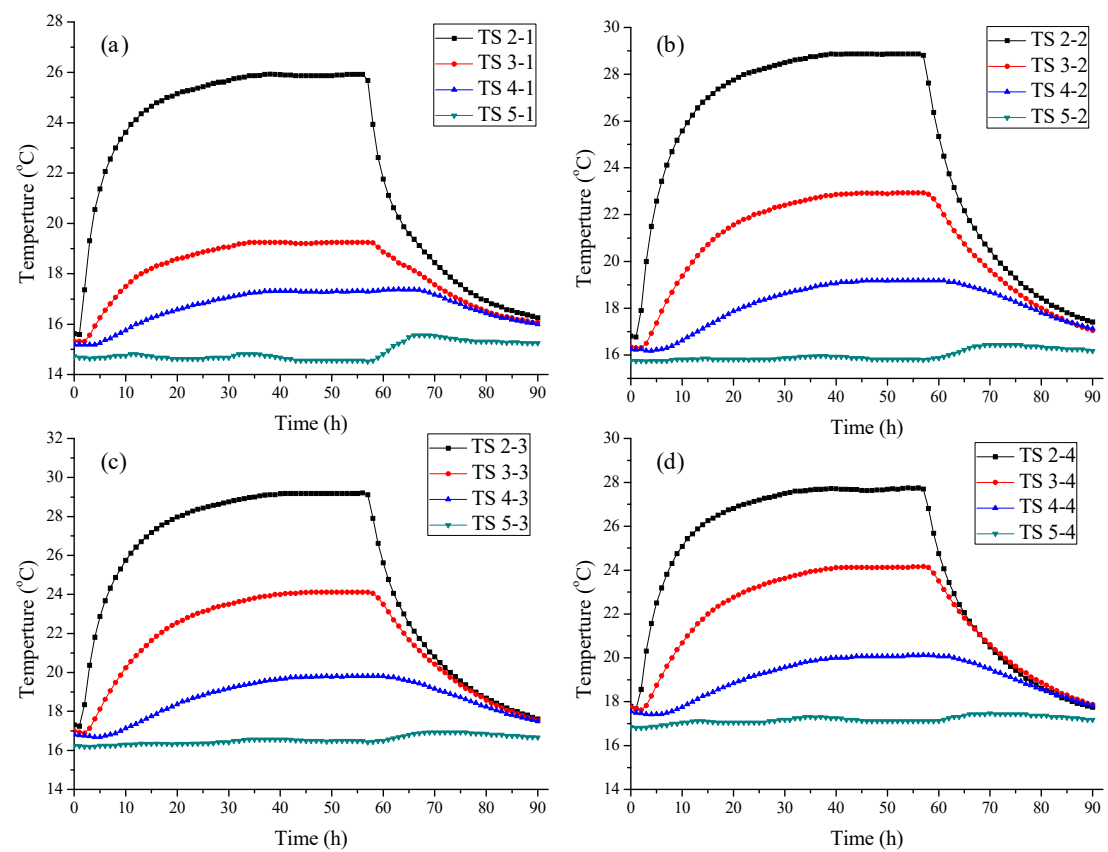

Figure 6. Time-dependent temperature curves of TSs of different distances to UT along each row in the fluid circulation of $50{ }^{\circ} \mathrm{C}$ : (a) No.1 TSs; (b) No.2 TSs; (c) No.3 TSs; (d) No.4 TSs.
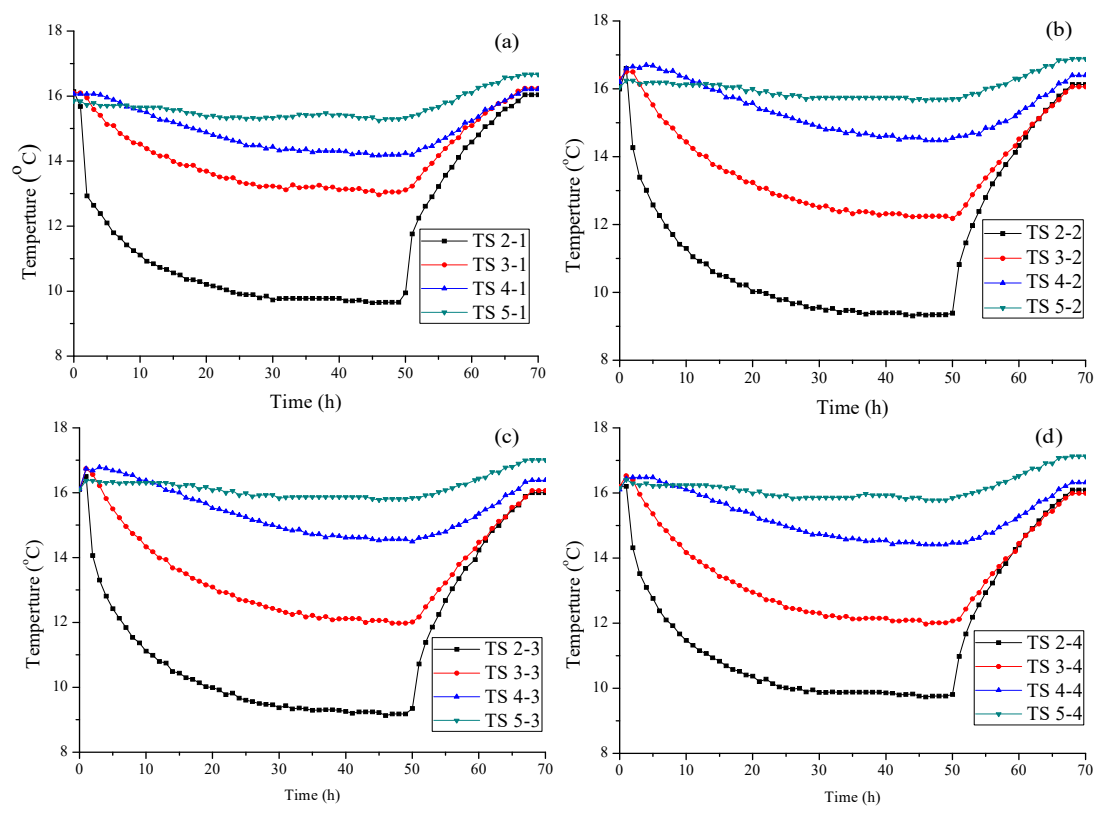

Figure 7. Time-dependent temperature curves of TSs of different distances to UT along each row in the fluid circulation of $-10^{\circ} \mathrm{C}$ : (a) No.1 TSs; (b) No.2 TSs; (c) No.3 TSs; (d) No.4 TSs. 
Comparing the curves in Figure 6, it can be found that closer to UT, a higher maximum temperature can occur and the temperature increment is larger. In another aspect, at the same time during circulation, the slope of the curve is greater, i.e., the temperature gradient is larger and has a higher temperature increasing rate. That is why, except Array 5 TSs, in almost all graphs (Figure 6a-d), Array 2 TSs (2-1, 2-2, 2-3 and 2-4) approach stable temperature values first. Likewise, in Figure 7 in the winter temperature of $-10^{\circ} \mathrm{C}$, heat conduction behaved similarly.

To better understand the heat influence on the temperature in soils along the depth, temperature variations of temperature sensors (TSs) in a same TS array number (such as TS 2-1, TS 2-2, TS 2-3, and TS 2-4) are also discussed and shown in Figures 8 and 9. They are located at the same distance to the U-tube but at different depths within the soils. Specifically, they are arranged in a column seen from the model elevation of Figure 4b and labeled as Array 1 TSs, Array 2 TSs, Array 3 TSs, and Array 4 TSs (such as Array 2 TSs includes TS 2-1, TS 2-2, TS 2-3, and TS 2-4). The temperature monitoring data indicated the very similar process on temperature variation along the depth just with very small amount change on temperature value. It proves that the vertical heat conduction is not much apparent than that in radial direction. In other words, the commonly-used assumption of one-dimensional thermal conduction theory in thermal parameters calculation is rational during the operation of GSHP system. Similarly, in Figure 9 of the winter case, temperature variations also show that radial heat conduction plays a role during the operation of the GSHP system. Figure $8 \mathrm{~d}$ further shows that the presence of the heat source of UT did not create an apparent increase of temperature in Array5 TSs (5-1, 5-2, 5-3, and 5-4), which also proved the rationality of choosing the TS of 4-3 as a criterion remark point to analyze the thermal balance. The fifth temperature sensor array was regarded as the influence boundary of heat conduction in this model test. At least closer No.4 TSs can show the temperature variation during testing. Additionally, muddy clay is the most concerned soil layer so that TS 4-3 is selected.
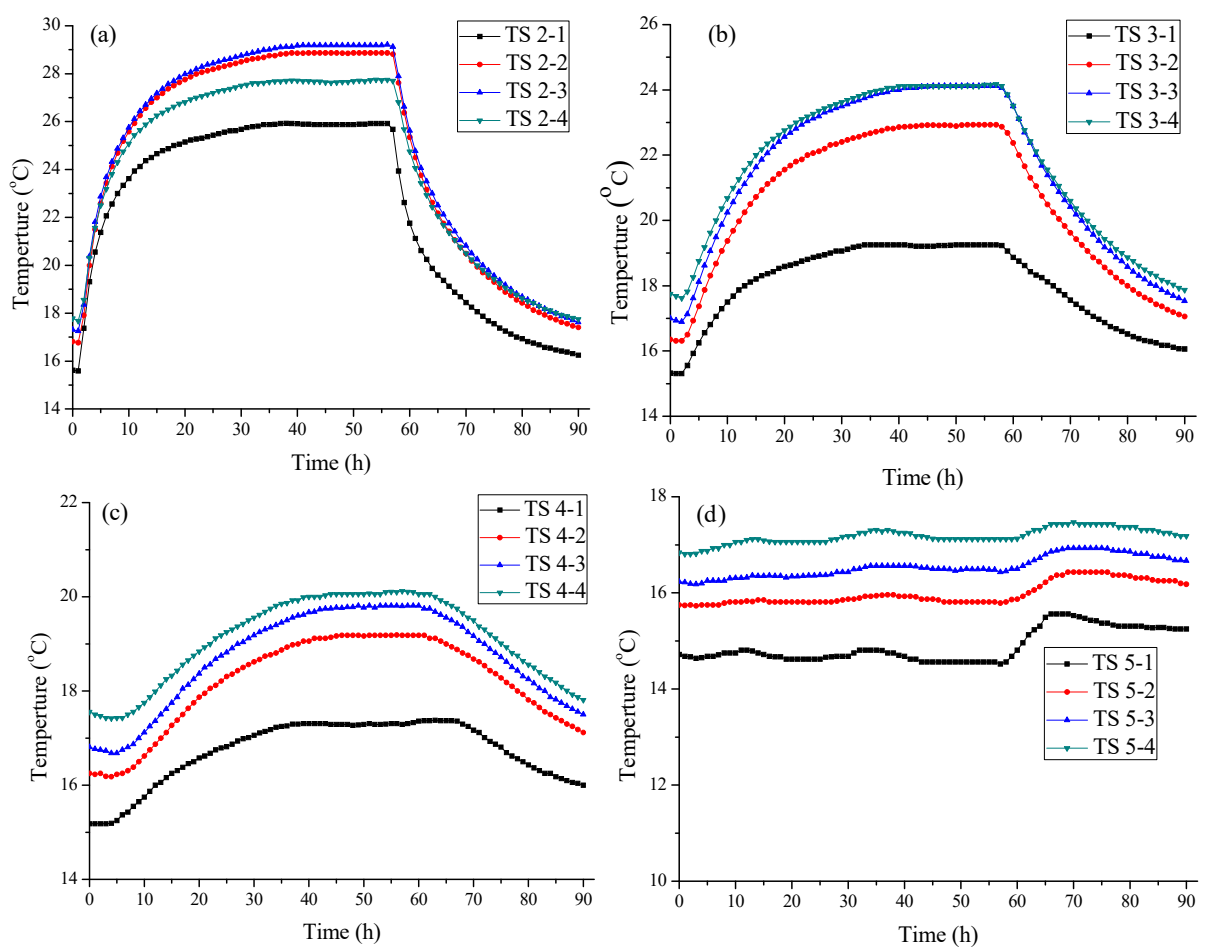

Figure 8. Time-dependent temperature curves of TSs of different distances to UT along each row in the fluid circulation of $50{ }^{\circ} \mathrm{C}$ : (a) Array 1 TSs; (b) Array 2 TSs; (c) Array 3 TSs; (d) Array 4 TSs.

Moreover, seen from the final stable temperature values, both in summer and winter cases, temperatures could hardly get back to the initial values, and are all raised a little (about $0.5^{\circ} \mathrm{C}$ ). This irreversibility seems not to be a contingency because the temperature increment did occur in all the TSs. 

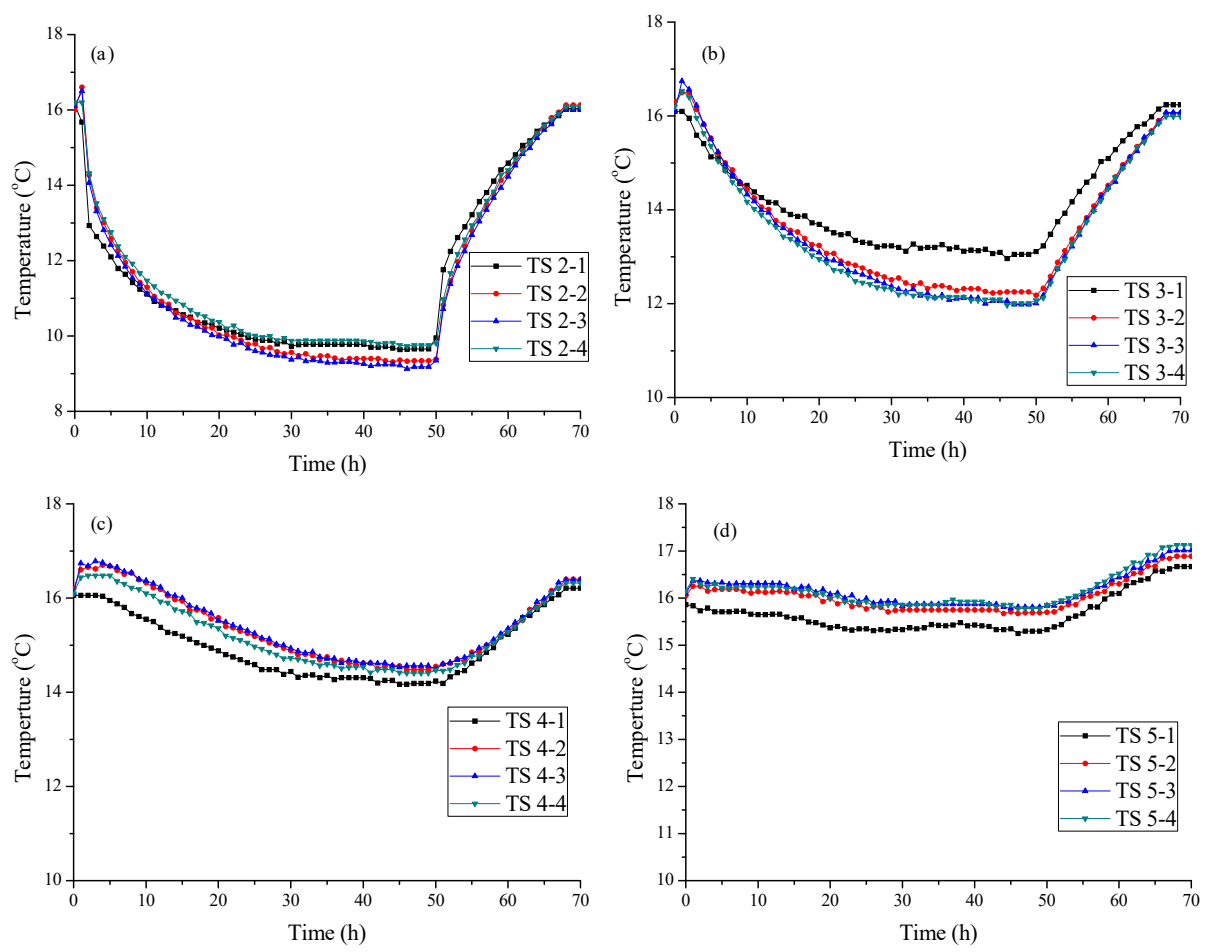

Figure 9. Time-dependent temperature curves of TSs of different distances to UT along each row in the fluid circulation of $-10^{\circ} \mathrm{C}$ : (a) Array 1 TSs; (b) Array 2 TSs; (c) Array 3 TSs; (d) Array 4 TSs.

\subsection{Thermal Balance Parameter Analysis}

To consider the thermal balance, a circle of one summer case and one winter case should be compared in the GSHP running. In this research program, two cases of $35^{\circ} \mathrm{C}$ from summer and $0{ }^{\circ} \mathrm{C}$ from winter were selected for analysis because the temperature differences in these two cases between the U-tube and surrounding soils were both around $17^{\circ} \mathrm{C}$. It means that this is the same thermal gradient compared to the beginning of tests. From Figure 10, it showed the temperature variations during muddy clay (the location of No.3 TS). It can be found that the time of temperature increase in the summer case is longer than the temperature decrease in the winter case. In other words, the time of heat storage and heat equilibrium in the summer case is longer than that in the winter case in Shanghai muddy clay. Since each group test was conducted under a same heat flux rate and a constant temperature and humidity circumstance, correspondingly the amount of heat storage is larger than the heat release in the muddy clay layer after one alternative cycle of GSHP operation.
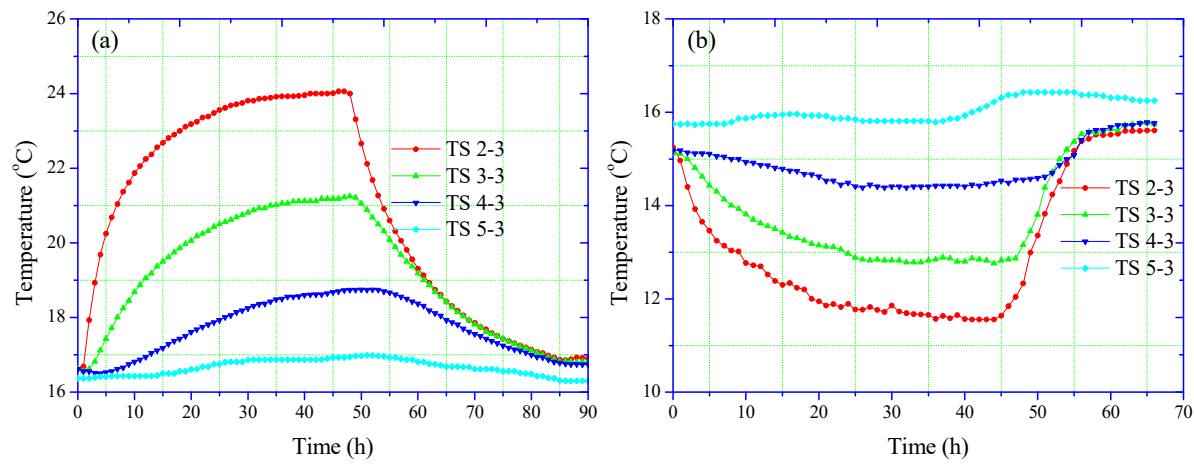

Figure 10. Time-dependent temperature curves of No.2 TSs: (a) $35^{\circ} \mathrm{C}$; (b) $0{ }^{\circ} \mathrm{C}$. 
To quantitatively analyze the thermal balance circumstance during the operation of GSHP system in our research program, two specific parameters were defined and deduced according to the monitoring data, which evaluated the thermal balance from the two aspects of temperature amount and running time. First is the temperature variation ratio $\alpha$. This parameter is defined to evaluate the degree of temperature changes by circulation based on the initial temperature difference between circulation fluid and surrounding soils. As shown in Equation (1), $i_{T}$ is referred to the temperature difference between the circulation fluid and the initial ground soils. The initial soil temperature was regarded as $17^{\circ} \mathrm{C}$; hence the $i_{T}$ evaluated as the temperature difference is respectively $18^{\circ} \mathrm{C}, 23^{\circ} \mathrm{C}, 28^{\circ} \mathrm{C}, 33^{\circ} \mathrm{C}$ in summer cases and $12{ }^{\circ} \mathrm{C}, 17^{\circ} \mathrm{C}, 22^{\circ} \mathrm{C}, 27^{\circ} \mathrm{C}$ in winter cases. $\Delta T$ is the final stable temperature change in each TS after the circulation ends.

$$
\alpha=\frac{\Delta T}{i_{T}}
$$

Shown as the results in Table 5, temperature variation ratios of No.3 TSs in the muddy clay layer (i.e., TS 2-3, TS 3-3, and TS 4-3) are all calculated. It is found that in the previous three cases either of summer circulations or winter circulations, the temperature variation ratios are almost the same. That is to say, the temperature variation (such as in TS 2-3 during the summer cases, they are $7.44{ }^{\circ} \mathrm{C}, 9.61^{\circ} \mathrm{C}$, $11.04{ }^{\circ} \mathrm{C}$; correspondingly $2.58{ }^{\circ} \mathrm{C}, 3.69^{\circ} \mathrm{C}, 4.49^{\circ} \mathrm{C}$ during the winter cases) increases as the initial temperature difference elevated. When enlarging $i_{T}$ by either increasing the circulation temperature in the summer cases or lowering it in the winter cases, the temperature variation became larger and the temperature variation ratios in the summer cases of $35^{\circ} \mathrm{C}, 40^{\circ} \mathrm{C}$, and $45^{\circ} \mathrm{C}$ or winter cases of $5{ }^{\circ} \mathrm{C}$, $0{ }^{\circ} \mathrm{C}$, and $-5^{\circ} \mathrm{C}$, just slightly changed and kept at the same level. But when $i_{T}$ was much higher, such as the summer case of $50^{\circ} \mathrm{C}$ or the winter case of $-10^{\circ} \mathrm{C}$, the temperature variation, no matter the temperature increment of $11.96^{\circ} \mathrm{C}$ under $50{ }^{\circ} \mathrm{C}$ or the temperature decrease amount $4.89^{\circ} \mathrm{C}$ under $-10^{\circ} \mathrm{C}$, they both change slightly respectively compared to the cases of $45^{\circ} \mathrm{C}\left(11.04{ }^{\circ} \mathrm{C}\right)$ or $-5{ }^{\circ} \mathrm{C}$ $\left(4.49^{\circ} \mathrm{C}\right)$. It can probably make sense that the heat exchange may approach a saturation state and the heat transfer rate got into heat equilibrium circumstance in heat exchange between the circulated fluid and the surrounding soils. That is to say, with an even higher initial temperature difference (thermal gradient), the final temperature variation would not change much.

Table 5. Thermal balance parameters of No.3 TSs in Shanghai muddy clay in fluid circulation.

\begin{tabular}{|c|c|c|c|c|c|c|c|c|c|c|}
\hline \multirow{3}{*}{$\begin{array}{c}\text { TS } \\
\text { Number }^{\text {a }}\end{array}$} & \multicolumn{8}{|c|}{ Temperature Variation Ratio $^{b}$} & \multicolumn{2}{|c|}{ Time Ratio } \\
\hline & \multicolumn{4}{|c|}{ Summer Case $\left({ }^{\circ} \mathrm{C}\right)$} & \multicolumn{4}{|c|}{ Winter Case $\left({ }^{\circ} \mathrm{C}\right)$} & \multirow{2}{*}{$\begin{array}{c}\text { Summer Case } \\
\left(35^{\circ} \mathrm{C}\right)\end{array}$} & \multirow{2}{*}{$\begin{array}{c}\text { Winter Case } \\
\left(0^{\circ} \mathrm{C}\right)\end{array}$} \\
\hline & 35 & 40 & 45 & 50 & 5 & 0 & -5 & -10 & & \\
\hline $2-3$ & 0.413 & 0.418 & 0.394 & 0.362 & 0.215 & 0.217 & 0.211 & 0.181 & 0.753 & 0.500 \\
\hline $3-3$ & 0.257 & 0255 & 0.244 & 0.219 & 0.120 & 0.121 & 0.120 & 0.110 & 0.788 & 0.655 \\
\hline $4-3$ & 0.118 & 0.117 & 0.118 & 0.095 & 0.030 & 0.032 & 0.032 & 0.026 & 0.883 & 0.750 \\
\hline
\end{tabular}

a-All the TSs are numbered in array number combined with elevation number such as 5-1 means in the fifth TS array at the first elevation (Figure 4); b-The initial soil temperature was $17^{\circ} \mathrm{C}$ in calculation; the thermal gradient was evaluated as the temperature difference of $18^{\circ} \mathrm{C}, 23^{\circ} \mathrm{C}, 28^{\circ} \mathrm{C}, 33^{\circ} \mathrm{C}$ in summer cases and $12{ }^{\circ} \mathrm{C}, 17^{\circ} \mathrm{C}, 22^{\circ} \mathrm{C}$, $27^{\circ} \mathrm{C}$ in winter cases.

The second parameter is the time ratio $\beta$, which is a relative value to evaluate the ability of the thermal equilibrium in the testing soil. Equation (2) indicates the value can be calculated from the time soil storing heat (temperature increasing) over the time releasing heat (temperature decreasing) in each case.

$$
\beta=t_{\text {heat storage }} / t_{\text {heat release }}
$$

As explained previously, it can be indicated that heat storage time in the summer case includes the fluid circulation period and heat equilibrium stage; heat release time equals to the time of recovery period. Likewise, the heat release time in the winter case can be estimated from the fluid circulation period to the equilibrium state; and the heat storage time is equal to the recovery period instead. For quantitative analysis, the corresponding time duration can be calculated in terms of the 
mathematical method, in which the slope of the tangent obtains the time points of the interval in each part (schematically shown as Figure 11). Since at the beginning of circulation, the temperature has some fluctuation and the real temperature rising point is specifically determined by a tangent line. The time interval between these two points is defined as the heat storage time in the summer case. Similarly, in the winter case, according to the method above, the time duration in each TS is gained and then correspondingly $\beta$ values can be deduced. It is surprising to notice that all the time ratios are smaller than 1 (Table 5 just presented the values in two representative cases of $35^{\circ} \mathrm{C}$ and $0{ }^{\circ} \mathrm{C}$ ). It means that the heat release time is always longer than the heat storage in Shanghai muddy clay. From the time ratio it can be also easily understood that during the running of GSHP system, under the same amount of heat, the time to release it would take more time after storing it. It indicated that, as for Shanghai muddy clay, the ability of heat storage is stronger than heat release, which also reflected that when subjected to the same circulation period for summer and winter cases, the heat storage amount would be higher than the heat release amount. The data in Table 5 provides good evidence for this. The temperature variation ratio respectively in the case of $35^{\circ} \mathrm{C}$ and $0{ }^{\circ} \mathrm{C}$ (these two cases have almost the same initial temperature difference) were remarkably different $(0.413,0.217)$. The temperature increment in the summer case of $35^{\circ} \mathrm{C}\left(7.44^{\circ} \mathrm{C}\right)$ was much higher than the temperature decrease amount in the winter case of $0^{\circ} \mathrm{C}$.

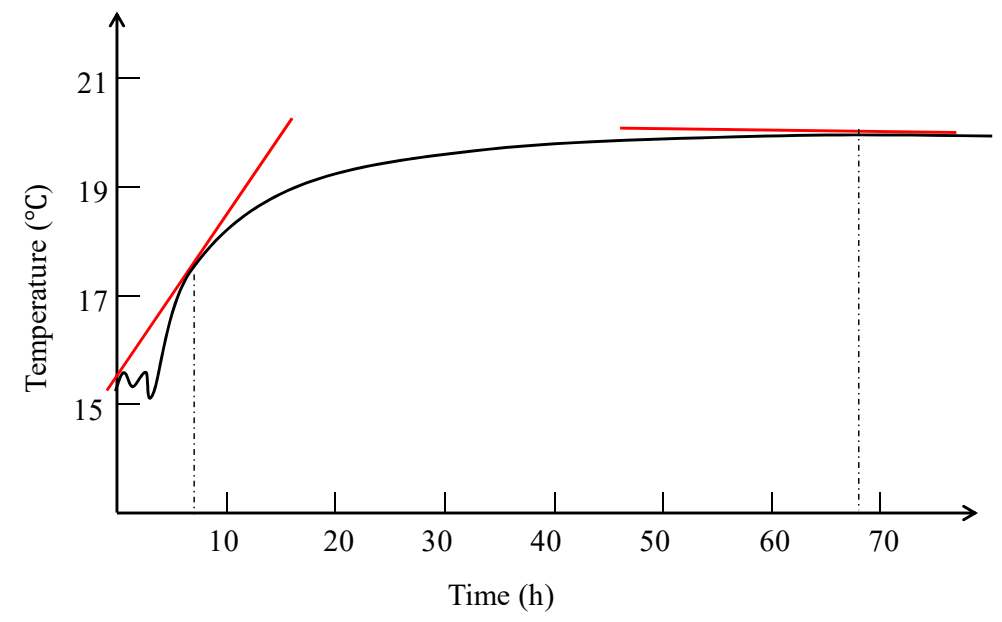

Figure 11. The determination of the temperature rising duration.

\subsection{Thermal Mattress Effect}

As explained in the heat mechanism analysis of Tang et al. [57] because the heat exchange in the winter case can easily approach the thermal equilibrium into the heat transfer saturated state while in summer case the heat transfers from the circulated fluid to the huge, ubiquitous surrounding soil, the thermal gradient can always be kept in a continuous gap to keep a long-term unsaturated heat transfer (Figure 12). In Shanghai, the duration for cooling in summer is almost twice the time of heating needed in winter. The cooling load is much greater than the heating load during the running of GSHP system. At the same time, according to the thermal balance factor comparisons on the summer and winter cases and the heat transfer mechanism process, even under a same external loading (no loading), the heat stored in the muddy clay is higher than the heat released. That is to say, the thermal balance problem can hardly be avoided during the alternation of the summer and winter circulations in Shanghai if no reasonable management and planning are conducted. In the second law of thermodynamics, no process is possible in which the only result is the heat transfer from a body of lower temperature to a body of higher temperature. Spontaneously, heat cannot flow from cold regions to hot regions without the external work being performed on the system, which is evident from the ordinary experience of refrigerant. It means that the heat transfer is not a reversible process. On the operation of GSHP system, dissipating excess heat into the ground is much easier than extracting 
heat from the soil. The heat exchange amount in the summer case is not consistent with that in the winter case during one single fluid circulation. The COP (coefficient of performance) of cooling in summer is greater than the heating in winter (It is generally $>5.5$ in summer and approximately 4.2 in winter $[12,33])$. Even if a well-designed GSHP system can make the ideal external thermal balance calculation during alternation of the summer and winter cases, without considering the properties of the muddy clay soil, the temperature increment and the recovery time are both limited to the recovery circumstance. The muddy clay soil has a strong capacity of heat storage, but a relatively poor heat release ability, i.e., for the same heating and cooling load, the GSHP system was unable to approach a thermal balance without complementing another energy source due to the intrinsic properties of Shanghai muddy clay.

Running of the GSHP system in the absence of considering the appropriate operation time in each case, the heat dissipated into the ground will be gradually accumulated and much more massive than the heat extracted out from the soil. The recovery process typically shows an asymptotic behavior, being fast at the start and then slowing down subsequently, and theoretically taking an infinite amount of time to reach its original state. However, practical intermittent utilization of GSHP system (e.g., 95\%) will occur much earlier, generally on time scales of the same order as seasonal alternation [14]. Testing data did indicate that the temperature of the soil surrounding the GSHP system is always in the trend of increasing after the recovery time, no matter four cases in summer circulation or four cases in winter circulation. Even though the amount of a circle operation of one summer and one winter is not so much $\left(0.5^{\circ} \mathrm{C}\right)$, the accumulative effect could not be ignored. What is worse is the long-term accumulative effect. It is defined as a thermal mattress effect in the underground soil, within which the temperature is relatively higher than ambient, and the heat could not release easily. Firstly, the sustainable usage of the GSHP system will be influenced accordingly. More critically, it will break the stability of initial ground temperature and influences the current ambient eco-environment, which has a potential influence of climate environment since the ground environment is a part of this whole global earth system by hydro-connection and air-motion. From this point, GSHP system should not be long-term operated as an independent energy supply system, and it is best to be joint-designed together with another energy system.

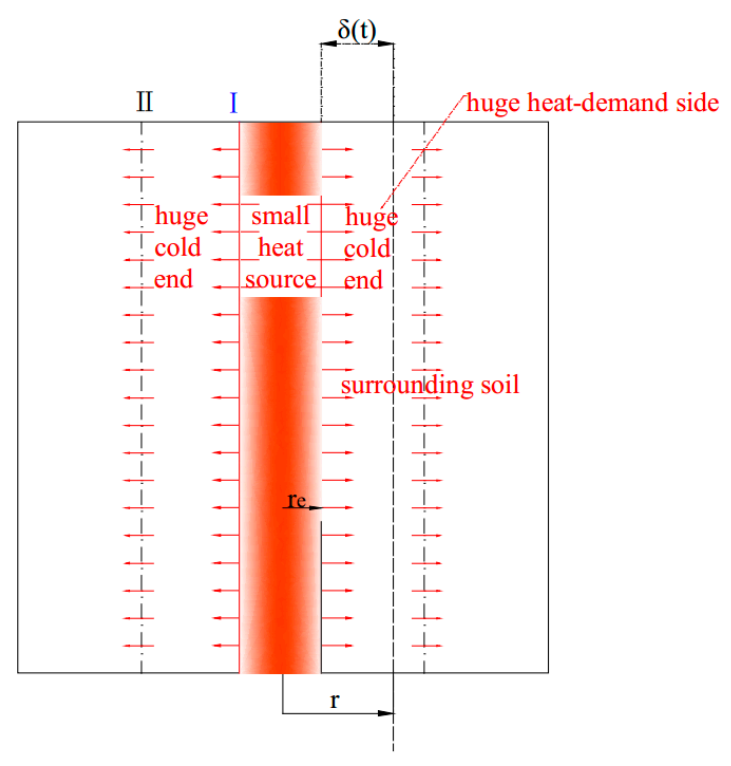

(a)

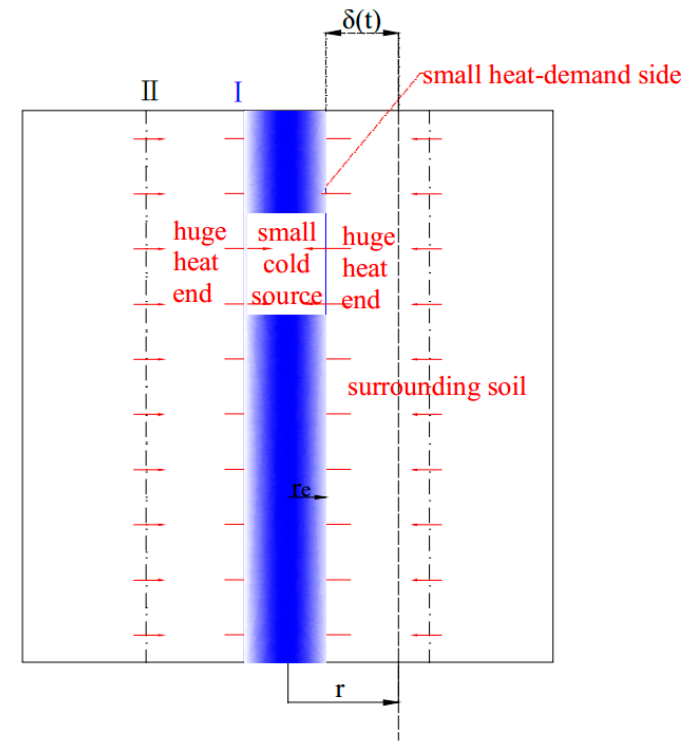

(b)

Figure 12. The heat transfer mechanism during the operation of the GSHP system: (a) summer case; (b) winter case. 


\section{Conclusions}

The thermal response test in situ in a borehole is both time consuming and expensive; particularly owing to the testing simplification in the complex construction field, it can only involve the summer case, and the long-term engineering and environment effect could not be comprehensively considered and evaluated. The objective of this present research program is to develop a large-scale laboratory modeling facility which could simulate the operation of GSHP system both in summer and winter cases. Preliminary analysis of the thermal balance problem is discussed. Some outcomes are concluded as follows:

1. Temperature variation induced by summer or winter case almost linearly increase with the elevated initial temperature difference between the circulation fluid and the ambient ground soil. However, the heat transfer rate could approach a balance by heat equilibrium in heat exchange. From this aspect, higher circulation temperatures could not always result in better efficiency of GSHP system.

2. From the comparison of temperature variation ratio and time ratio values in summer and winter circulations, Shanghai muddy clay is proved to be a geo-material with strong heat storage, but poor heat release ability.

3. Thermal balance of heat dissipated to and extracted from muddy clay can hardly be achieved during the alternation between summer and winter cycles without other external effort and appropriate management. This is explained by the irreversible and asymmetric heat conduction characteristics based on monitoring data and also the second law of thermodynamics.

4. The thermal mattress effect in muddy clay soil will potentially occur after single long-term operation of GSHP system in the absence of corresponding management and involving the environment evaluation.

All these conclusions are provided the valuable instructions for the incoming large-area utilization of GSHP system in Shanghai. GSHP system should not be long-term operated as an independent energy supply system and it is best to be joint-designed together with another energy system.

Author Contributions: Methodology, validation, investigation, writing-original draft preparation, J.Z.; conceptualization, writing-review and revision, Y.T.; engineering background materials and data check, P.W.; literature analysis, Z.L.; figure and table re-editing, C.W.

Funding: This research received no external funding.

Acknowledgments: The research work herein was supported by the National Natural Science Foundation of China (Grant No. 41702299), Shanghai Sailing Program (Grant No. 02302360185) and Talent Program, Tongji University (2015KJ010). The authors are deeply indebted to these financial supporters.

Conflicts of Interest: The authors declare no conflict of interest.

\section{References}

1. Sanner, B.; Karytsas, C.; Mendrinos, D.; Rybach, L. Current Status of Ground Source Heat Pumps and Underground Thermal Energy Storage in Europe. Geothermics 2003, 32, 579-588. [CrossRef]

2. Eugster, W.J.; Sanner, B. Technological Status of Shallow Geothermal Energy in Europe. In Proceedings of the European Ggeothermal Congres, Unterhaching, Germany, 30 May-1 June 2007.

3. Zhang, H.F.; Ge, X.S.; Ye, H.; Jiao, D.S. Heat Conduction and Heat Storage Characteristics of Soils. Appl. Therm. Eng. 2007, 27, 369-373. [CrossRef]

4. Salomone, L.A.; William, D.; Kavacs Tamami, K. Thermal Performance of Fine-Grained Soils. J. Geotech. Eng. ASCE 1990, 110, 359-374. [CrossRef]

5. Sanner, B. Shallow Geothermal Energy. In The European Summer School on Geothermal Energy Applications; GHC Bulletin; University of Oradea: Oradea, Romania, 2001; pp. 191-212.

6. Brandl, H. Energy Foundations and Other Thermo-Active Ground Structures. Geotechnique 2006, 56, 81-122. [CrossRef] 
7. De Moel, M.; Peter, M.; Abdelmalek, B.; Singh, R.M.; Sun, J.L. Technological Advances and Applications of Geothermal Energy Pile Foundations and Their Feasibility in Australia. Renew. Sustain. Energy Rev. 2010, 14, 2683-2696. [CrossRef]

8. Hamada, Y.; Hisashi, S.; Makoto, N.; Hideki, K.; Kiyoshi, O. Field Performance of an Energy Pile System for Space Heating. Energy Build. 2007, 39, 517-524. [CrossRef]

9. He, M.M.; Lam, H.N. Study of Geothermal Seasonal Cooling Storage System with Energy Piles. Proc. Ecostock. 2006. Available online: https://intraweb.stockton.edu/eyos/energy_studies/content/docs/final_papers/11a-2. pdf (accessed on 30 September 2018).

10. Doughty, C.; Karsten, P. A Semianalytical Solution for Heat-Pipe Effects near High-Level Nuclear Waste Packages Buried in Partially Saturated Geological Media. Int. J. Heat Mass Transf. 1988, 31, 79-90. [CrossRef]

11. Salvalai, G. Implementation and Validation of Simplified Heat Pump Model in Ida-Ice Energy Simulation Environment. Energy Build. 2012, 49, 132-141. [CrossRef]

12. Liu, X.H. The Research of Soil's Temperature of Double U-Tube Ground Source Heat Pump and Economic Analysis of the Heat Pump System. Master's Thesis, Tianjin University, Tianjin, China, 2007.

13. Miara, M.; Günther, D.; Langner, R.; Helmling, S. The Outcomes and Lessons Learned from the Wide-Scale Monitoring Campaign of Heat Pumps in Family Dwellings in Germany. In Proceedings of the 11th IEA Heat Pump Conference, Montreal, QC, Canada, 12-16 May 2014.

14. Axelsson, G.; Valgardur, S.; Grímur, B.; Liu, J. Sustainable Management of Geothermal Resources and Utilization for 100-300 Years. In Proceedings of the World Geothermal Congress, Antalya, Turkey, 24-29 April 2005.

15. Herzen, R.V.; Maxwell, A. The Measurement of Thermal Conductivity of Deep-Sea Sediments by a Needle-Probe Method. J. Geophys. Res. 1959, 64, 1557-1563. [CrossRef]

16. Manohar, K.; Yarbrough, D.W.; Booth, J.R. Measurement of Apparent Thermal Conductivity by the Thermal Probe Method. J. Test. Eval. ASTM-JTEVA 2000, 28, 345-351.

17. Abuel-Naga, H.M.; Bergado, D.T.; Bouazza, A.; Pender, M.J. Thermal Conductivity of Soft Bangkok Clay from Laboratory and Field Measurements. Eng. Geol. 2009, 105, 211-219. [CrossRef]

18. Al-Malah, K.; Basim, A.-J. Clay-Based Heat Insulator Composites: Thermal and Water Retention Properties. Appl. Clay Sci. 2007, 37, 90-96. [CrossRef]

19. Azadi, P.; Farnood, R.; Yan, N. Fem-Dem Modeling of Thermal Conductivity of Porous Pigmented Coatings. Comput. Mater. Sci. 2010, 49, 392-399. [CrossRef]

20. Chen, Y.L.; Azzam, R.; Fernandez-Steeger, T.M.; Li, L. Studies on Construction Pre-Control of a Connection Aisle between Two Neighbouring Tunnels in Shanghai by Means of 3d Fem, Neural Networks and Fuzzy Logic. Geotech. Geol. Eng. 2008, 27, 155-167. [CrossRef]

21. Monfared, M.; Sulem, J.; Delage, P.; Mohajerani, M. A Laboratory Investigation on Thermal Properties of the Opalinus Claystone. Rock Mech. Rock Eng. 2011, 44, 735-747. [CrossRef]

22. O'Donnell, J.A.; Romanovsky, V.E.; Harden, J.W.; McGuire, A.D. The Effect of Moisture Content on the Thermal Conductivity of Moss and Organic Soil Horizons from Black Spruce Ecosystems in Interior Alaska. Soil Sci. 2009, 174, 646-651. [CrossRef]

23. Ye, W.M.; Cui, Y.J.; Qian, L.X.; Chen, B. An Experimental Study of the Water Transfer through Confined Compacted Gmz Bentonite. Eng. Geol. 2009, 108, 169-176. [CrossRef]

24. Yun, T.S.; Santamarina, J.C. Fundamental Study of Thermal Conduction in Dry Soils. Granul. Matter 2007, 10, 197-207. [CrossRef]

25. Gangadhara Rao, M.V.B.B.; Kolay, P.K.; Singh, D.N. Thermal Characteristics of a Class F Fly Ash. Cem. Concr. Res. 1998, 28, 841-846. [CrossRef]

26. Gangadhara-Rao, M.V.B.B.; Singh, D.N. A Generalized Relationship to Estimate Thermal Resistivity of Soils. Can. Geotech. J. 1999, 36, 767-773. [CrossRef]

27. Hammerschmidt, U. A Quasi-Steady State Technique to Measure the Thermal Conductivity. Int. J. Thermophys. 2003, 24, 1291-1312. [CrossRef]

28. Zhen, R.; Yin, W.Y.; Shi, Y.B.; Liu, Q.H. Thermal Accumulation Effects on the Transient Temperature Responses in Ldmosfets under the Impact of a Periodic Electromagnetic Pulse. IEEE Trans. Electron Devices 2010, 57, 345-352. 
29. Eaton, S.M.; Zhang, H.; Ng, M.L.; Li, J.Z.; Chen, W.J.; Ho, S.; Herman, P.R. Transition from Thermal Diffusion to Heat Accumulation in High Repetition Rate Femtosecond Laser Writing of Buried Optical Waveguides. Opt. Express 2008, 16, 9443-9458. [CrossRef]

30. Esen, H.; Mustafa, I. In-Situ Thermal Response Test for Ground Source Heat Pump System in Elazığ, Turkey. Energy Build. 2009, 41, 395-401. [CrossRef]

31. Juodkazis, S.; Li, M.; Kotin, D.; Maksimov, I.; Vanagas, E.; Misawa, H. Thermal Effects in Three-Dimensional Recording by Femto/Nano-Second Pulses. In Ultrafast Phenomena in Semiconductors and Nanostructure Materials X, Proceedings of the Integrated Optoelectronic Devices 2006, San Jose, CA, USA, 21-26 January 2006; SPIE: Bellingham, WA, USA, 2006; Volume 6118, p. 611807. [CrossRef]

32. Juodkazis, S.; Misawa, H.; Maksimov, I. Thermal Accumulation Effect in Three-Dimensional Recording by Picosecond Pulses. Appl. Phys. Lett. 2004, 85, 5239. [CrossRef]

33. Karabacak, R.; Acar, S..G.; Kumsar, H.; Gökgöz, A.; Kaya, M.; Tülek, Y. Experimental Investigation of the Cooling Performance of a Ground Source Heat Pump System in Denizli, Turkey. Int. J. Refrig. 2011, 34, 454-465. [CrossRef]

34. Ye, W.M.; Wan, M.; Chen, B.; Chen, Y.G.; Cui, Y.J.; Wang, J. Temperature Effects on the Unsaturated Permeability of the Densely Compacted Gmz01 Bentonite under Confined Conditions. Eng. Geol. 2012, 126, 1-7. [CrossRef]

35. Abuel-Naga, H.M.; Bergado, D.T.; Bouazza, A. Thermally Induced Volume Change and Excess Pore Water Pressure of Soft Bangkok Clay. Eng. Geol. 2007, 89, 144-154. [CrossRef]

36. Cleall, P.J.; Melhuish, T.A.; Thomas, H.R. Modelling the Three-Dimensional Behaviour of a Prototype Nuclear Waste Repository. Eng. Geol. 2006, 85, 212-220. [CrossRef]

37. Cui, Y.J.; Gao, Y.B.; Ferber, V. Simulating the Water Content and Temperature Changes in an Experimental Embankment Using Meteorological Data. Eng. Geol. 2010, 114, 456-471. [CrossRef]

38. Gera, F.; Hueckel, T.; Peano, A. Critical Issues in Modelling the Long-Term Hydro-Thermo-Mechanical Performance of Natural Clay Barriers. Eng. Geol. 1996, 41, 17-33. [CrossRef]

39. Heitman, J.L.; Xiao, X.; Horton, R.; Sauer, T.J. Sensible Heat Measurements Indicating Depth and Magnitude of Subsurface Soil Water Evaporation. Water Resour. Res. 2008, 44. [CrossRef]

40. Jung, Y.-B.; Park, E.-S.; Chung, S.-K.; Kim, H.-Y. Coupled Hydro-Thermal Modeling of Ice Ring Formation around a Pilot Lng Cavern in Rock. Eng. Geol. 2011, 118, 122-133. [CrossRef]

41. Kimura, R.; Kamichika, M.; Takayma, N.; Matsuoka, N.; Zhang, X. Heat Balance and Soil Moisture in Loess Plateau, China. J. Agric. Meteorol. 2004, 60, 103-113. [CrossRef]

42. Nickolaenko, A.P. Concept of Planetary Thermal Balance and Global Warming. J. Geophys. Res. $2009,114$. [CrossRef]

43. Ribast, J.R.; Spinard, B.I. A Simplified Thermal Analysis of a Nuclear Waste Repository. Ann. Nucl. Energy 1989, 16, 371-382.

44. Wu, S.H.; Jansson, P.E.; Zhang, X.Y. Modelling Temperature, Moisture and Surface Heat Balance in Bare Soil under Seasonal Frost Conditions in China. Eur. J. Soil Sci. 2011, 62, 780-796. [CrossRef]

45. He, Y.D.; Meng, Z. Core of Long-Term Effective Develpment of Ground-Source Heat Pump-Dynamic Heat Balance of Rock and Soil between Summer and Winter. HVEAC 2009, 39, 74-77.

46. Meng, T.; Di, Y.; Liu, L.; Ma, F.; Zhao, Y. Research of Ground Heat Balance of Ground Source Heat Pump. In Proceedings of the 2009 International Conference on Energy and Environment Technology, Guilin, China, 16-18 October 2009; pp. 777-781. [CrossRef]

47. Wang, S.Q.; Zhang, X.; Bao, Q.; Liu, J.; Gao, J. Study on the Influences of Thermal Imbalance Ratio on Soil Temperature Field under Different Arrangment Forms of Gethermal Heat Exchanger. Build. Sci. 2010, 26, 64-67.

48. Xu, Y.-S.; Shen, S.-L.; Du, Y.-J. Geological and Hydrogeological Environment in Shanghai with Geohazards to Construction and Maintenance of Infrastructures. Eng. Geol. 2009, 109, 241-254. [CrossRef]

49. Dassargues, A.; Biver, P.; Monjoie, A. Geotechnical Properties O F the Quaternary Sediments in Shanghai. Eng. Geol. 1991, 31, 71-90. [CrossRef]

50. Xie, N.; Sun, J. Rheology Behavior of Shanghai Clays. J. Tongii Univ. 1996, 24, 233-237.

51. Zhou, X.M.; Yuan, L.Y.; Cai, J.Q.; Hou, X.J. Analysis of Soft Soil Distributed Characteristics and Deformation Examples of Shanghai Area. Shanghai Geol. 2005, 4, 6-10. 
52. Tang, Y.Q.; Yang, P.; Zhao, S.K.; Zhang, X.; Wang, J.X. Characteristics of Deformation of Saturated Soft Clay under the Load of Shanghai Subway Line No. 2. Environ. Geol. 2008, 54, 1197. [CrossRef]

53. Tang, Y.-Q.; Zhou, J.; Liu, S.; Yang, P.; Wang, J.-X. Test on Cyclic Creep Behavior of Mucky Clay in Shanghai under Step Cyclic Loading. Environ. Earth Sci. 2011, 63, 321-327. [CrossRef]

54. D2435, ASTM Standard. D2435/D2435m-11. Standard Test Method for One-Dimensional Consolidation Properties of Soils Using Incremental Loading; Annual Book of ASTM (American Society of Testing Material) Standards, 04.08; ASTM International: West Conshohocken, PA, USA, 2011.

55. Ladd, R.S. Preparing Test Specimens Using Undercompaction. Geotech. Test. J. 1978, 1, 16-23.

56. Qu, C.-S.; Chen, H.-Y.; Cao, Y.; Xu, D. Characteristics of and Causes of Variation in Shallow Geothermal Field Temperature in the Shanghai Area. Shanghai Land Resour. 2013, 34, 73-76.

57. Tang, Y.Q.; Zhou, J.; Zhang, M.D.; Liu, Y.T. Research on the Thermal Conductivity and Moisture Migration Characteristics of Shanghai Mucky Clay. I: Experimental Modeling. Bull. Eng. Geol. Environ. 2015, 74, 577-593. [CrossRef]

(C) 2019 by the authors. Licensee MDPI, Basel, Switzerland. This article is an open access article distributed under the terms and conditions of the Creative Commons Attribution (CC BY) license (http://creativecommons.org/licenses/by/4.0/). 